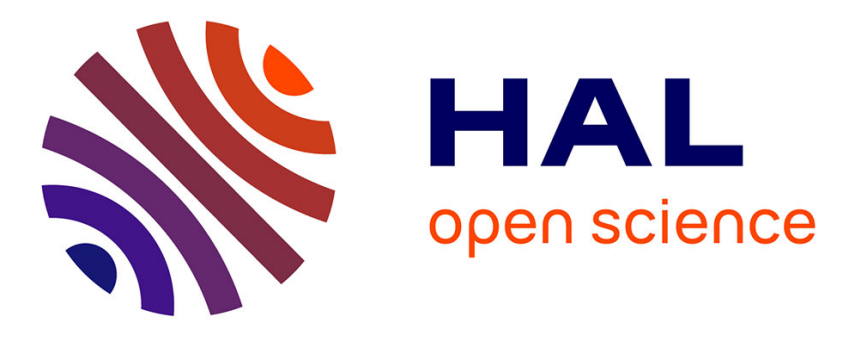

\title{
Designing a Thermoelectric Copper-Rich Sulfide from a Natural Mineral: Synthetic Germanite Cu22Fe8Ge4S32
}

\author{
Ventrapati Pavan Kumar, Laura Paradis-Fortin, P. Lemoine, Vincent
} Caignaert, Bernard Raveau, Bernard Malaman, Gérard Le Caër, Stéphane Cordier, Emmanuel Guilmeau

\section{To cite this version:}

Ventrapati Pavan Kumar, Laura Paradis-Fortin, P. Lemoine, Vincent Caignaert, Bernard Raveau, et al.. Designing a Thermoelectric Copper-Rich Sulfide from a Natural Mineral: Synthetic Germanite Cu22Fe8Ge4S32. Inorganic Chemistry, 2017, 56 (21), pp.13376-13381. 10.1021/acs.inorgchem.7b02128 . hal-01640116

\section{HAL Id: hal-01640116 \\ https://hal-univ-rennes1.archives-ouvertes.fr/hal-01640116}

Submitted on 1 Feb 2018

HAL is a multi-disciplinary open access archive for the deposit and dissemination of scientific research documents, whether they are published or not. The documents may come from teaching and research institutions in France or abroad, or from public or private research centers.
L'archive ouverte pluridisciplinaire HAL, est destinée au dépôt et à la diffusion de documents scientifiques de niveau recherche, publiés ou non, émanant des établissements d'enseignement et de recherche français ou étrangers, des laboratoires publics ou privés. 


\section{Designing a Thermoelectric Copper-rich Sulfide from a}

\section{Natural Mineral: Synthetic Germanite $\mathrm{Cu}_{22} \mathrm{Fe}_{8} \mathrm{Ge}_{4} \mathrm{~S}_{32}$}

Ventrapati Pavan Kumar, ${ }^{1}$ Laura Paradis-Fortin, ${ }^{1,2}$ Pierric Lemoine, ${ }^{2}$ Vincent

Caignaert, ${ }^{1}$ Bernard Raveau, ${ }^{1}$ Bernard Malaman, ${ }^{3}$ Gérard Le Caër, ${ }^{4}$ Stéphane Cordier, ${ }^{2}$ Emmanuel Guilmeau ${ }^{1, *}$

${ }^{1}$ Laboratoire CRISMAT, UMR-CNRS 6508, ENSICAEN, 6 Boulevard du Maréchal Juin, 14050 Caen Cedex 04, France

2 Institut des Sciences Chimiques de Rennes (ISCR) - UMR UR1-CNRS 6226, Université de Rennes I, Campus de Beaulieu, Bâtiment 10A, 35042 Rennes Cedex, France.

${ }^{3}$ Institut Jean Lamour, UMR-CNRS 7198, Université de Lorraine, Faculté des Sciences et Technologies, B.P. 70239, 54506 Vandœuvre-lès-Nancy Cedex, France

${ }^{4}$ Institut de Physique de Rennes (IPR), UMR UR1-CNRS 6251, Université de Rennes I, Campus de Beaulieu, Bâtiment 11A, F-35042 Rennes Cedex, France

*E-mail address: emmanuel.guilmeau@ensicaen.fr, Phone: +33 231451367. 


\begin{abstract}
This study shows that the design of copper rich sulfides by mimicking natural minerals allows a new germanite-type sulfide $\mathrm{Cu}_{22} \mathrm{Fe}_{8} \mathrm{Ge}_{4} \mathrm{~S}_{32}$ with promising thermoelectric properties to be synthesized. The Mössbauer spectroscopy and X-ray diffraction analyses evidence that the structure of our synthetic compound differs from that of the natural germanite mineral $\mathrm{Cu}_{26} \mathrm{Fe}_{4} \mathrm{Ge}_{4} \mathrm{~S}_{32}$ by its much higher $\mathrm{Cu}^{+} / \mathrm{Cu}^{2+}$ ratio and different cationic occupancies. The coupled substitution of $\mathrm{Cu}^{+} / \mathrm{Fe}^{3+}$ for $\mathrm{Cu}^{2+}$ in the $\mathrm{Cu}_{26-x} \mathrm{Fe}_{4+x} \mathrm{Ge}_{4} \mathrm{~S}_{32}$ series also appears as a promising approach for increasing the $\mathrm{Cu}^{+}$ content in sulfides with a tetrahedral framework, which strongly affects the thermoelectric properties. The electrical resistivity, which decreases slightly as the temperature increases, shows that these materials exhibit a semiconducting behavior, but are at the border of a metallic state. The magnitudes of the electrical resistivity and Seebeck coefficient increase with $x$, which suggests that $\mathrm{Fe}$ for $\mathrm{Cu}$ substitution decreases the hole concentration. The thermal conductivity decreases as the temperature increases leading to a moderately low value of $1.2 \mathrm{~W} \mathrm{~m}^{-1} \mathrm{~K}^{-1}$ and a maximum $\mathrm{ZT}$ value of 0.17 at $575 \mathrm{~K}$.
\end{abstract}

Keywords: Thermoelectric, Sulfide, germanite, colusite, Mechanical alloying 


\section{Introduction}

Copper-rich sulfides represent a potential source for the realization of eco-friendly and low cost $p$-type thermoelectrics, with rather high figure of merit $Z T=S^{2} T / \rho \kappa$, where $S$ is the Seebeck coefficient, $T$ is the absolute temperature, $\rho$ is the electrical resistivity and $\kappa$ is the thermal conductivity. The $p$-type conductivity of these compounds is governed by the value of the redox potential of the couple $\mathrm{Cu}^{+} / \mathrm{Cu}^{2+}$, but requires the presence of a majority of univalent copper. This suggests that the existence of rather high $p$-type conductivity necessary for the generation of high-performances thermoelectric properties originates from the great ability of univalent copper to accommodate tetrahedral coordination and from the $\mathrm{CuS}_{4}$ tetrahedra to share edges and vertices to form tridimensional $\mathrm{Cu}-\mathrm{S}$ frameworks favorable to the delocalization of $p$ type carriers.

Based on the above statements, we believe that the crystal chemistry of copper-rich natural minerals should be taken into consideration for the generation of new $p$-type thermoelectrics. This is exemplified by the stannites $\mathrm{Cu}_{2} \mathrm{ZnMS}_{4}(M=\mathrm{Sn}, \mathrm{Ge}){ }^{1,2}$ the derivatives of the tetrahedrite $\mathrm{Cu}_{12} \mathrm{Sb}_{4} \mathrm{~S}_{13},{ }^{3-5}$ of the colusite $\mathrm{Cu}_{26} \mathrm{~V}_{2} \mathrm{Sn}_{6} \mathrm{~S}_{32},{ }^{6-8}$ of the bornite $\mathrm{Cu}_{5} \mathrm{FeS}_{4},{ }^{9-11}$ and of the stannoidite $\mathrm{Cu}_{8+x} \mathrm{Fe}_{3-x} \mathrm{Sn}_{2} \mathrm{~S}_{12},{ }^{12}$ which all exhibit attractive thermoelectric properties. In this respect, the mineral germanite $\mathrm{Cu}_{26} \mathrm{Fe}_{4} \mathrm{Ge}_{4} \mathrm{~S}_{32}$ appears as a possible thermoelectric material, as its copper-rich structure is purely tetrahedral, i.e. consists of corner and edge-sharing $\mathrm{CuS}_{4}, \mathrm{FeS}_{4}$ and $\mathrm{GeS}_{4}$ tetrahedra, but differs from the previous natural minerals by a higher $\mathrm{Cu}^{2+}$ content as shown from its formula $\mathrm{Cu}^{+}{ }_{16} \mathrm{Cu}^{2+}{ }_{10} \mathrm{Fe}^{3+}{ }_{4} \mathrm{Ge}^{4+}{ }_{4} \mathrm{~S}^{2-}{ }_{32 .}{ }^{13}$ Thus, we have embarked in the investigation of the $\mathrm{Cu}-\mathrm{Fe}-\mathrm{Ge}-\mathrm{S}$ system, with a focus set on the germanite structure. We report herein for the first time on a synthetic copper deficient germanite $\mathrm{Cu}_{22} \mathrm{Fe}_{8} \mathrm{Ge}_{4} \mathrm{~S}_{32}$ and on its thermoelectric properties. 


\section{Experimental Section}

Polycrystalline samples of $\mathrm{Cu}_{26-x} \mathrm{Fe}_{4+x} \mathrm{Ge}_{4} \mathrm{~S}_{32}(0 \leq x \leq 4)$ were synthesized by mechanical alloying followed by Spark Plasma Sintering. All sample preparation and handling of powders were performed in argon filled glove box with oxygen content of $<1 \mathrm{ppm}$. Stoichiometric amounts of $\mathrm{Cu}(99.9 \%$, Alfa Aesar), Fe (99.9 \%, Alfa Aesar), Ge (99.9 \%, Alfa Aesar) and S (99.99\%, Alfa Aesar) were loaded in a $25 \mathrm{ml}$ tungsten carbide jar under argon atmosphere. High-energy ball-milling was performed in a Fritsch Pulverisette 7 Premium line planetary ball-mill operating at RT at a disc rotation speed of $600 \mathrm{rpm}$. The jar contains 7 balls of $10 \mathrm{~mm}$ diameter. Jar and balls are made of tungsten carbide. The powder-to-ball weight ratio we used was 1:14. Powders were milled in argon atmosphere for $6 \mathrm{~h}$. The resulting powders were then ground and sieved down to $150 \mu \mathrm{m}$. Powders were then placed in tungsten carbide dies of $10 \mathrm{~mm}$ diameter and densified by Spark Plasma Sintering (SPS - FCT HPD 25) at $873 \mathrm{~K}$ for $30 \mathrm{~min}$ under a pressure of $64 \mathrm{MPa}$ (heating and cooling rate of $50 \mathrm{~K} / \mathrm{min}$ and $20 \mathrm{~K} / \mathrm{min}$, respectively). This produced $10 \mathrm{~mm}$ diameter pellets, $c a .7 \mathrm{~mm}$ thick, with geometrical densities greater than $96 \%$.

Powder X-ray diffraction (PXRD) measurements were performed using a D8 advance diffractometer with silicium band lynx eyes detector $(\mathrm{Cu} \mathrm{K \alpha}$ radiation with $\mathrm{Ge}$ (111) monochromator). Data were collected with the addition of 6 scans over the angular range $10 \leq 2 \theta /{ }^{\circ} \leq 140$ with a step size of $0.0105^{\circ}$, and a step time of $1.3 \mathrm{sec}$. PXRD patterns were refined by Rietveld analysis using the FullProf and WinPlotr software packages. ${ }^{14,15}$ The shape of the diffraction peaks was modelled using a Thompson-CoxHastings pseudo-Voigt profile function. ${ }^{16}$ Zero-point shift and asymmetry parameters were systematically refined, and the background contribution was manually estimated. 
Lattice parameter, atomic positions, and isotropic displacement parameters (i.e. DebyeWaller factors: $B_{\text {iso }}$ ) were finally refined.

Room temperature Hall effect measurements were carried out using Physical Properties Measurement System (PPMS; Quantum Design) under an applied magnetic field up to 9T. However, it is difficult to extract reliable carrier concentrations due to anomalous contribution. Attempts to calculate the carrier concentration using the approximation of single parabolic band conduction model, using the formula $p=1 / R_{H} \cdot e$, where $\mathrm{e}$ is the electronic charge, gives unrealistic values.

${ }^{57} \mathrm{Fe}$ Mössbauer spectra were measured at $\mathrm{T}=300 \mathrm{~K}$ in transmission geometry with a spectrometer operated in the conventional constant-acceleration mode. Polycrystalline absorbers, with natural abundance of ${ }^{57} \mathrm{Fe}$ and thickness of $\sim 15 \mathrm{mg} \mathrm{cm}^{-2}$, were used. Sources were kept at room temperature $(R T)$ to collect ${ }^{57} \mathrm{Fe}$ Mössbauer spectra. The source was ${ }^{57} \mathrm{Co}$ in $\mathrm{Rh}$ matrix with a nominal strength of $25 \mathrm{mCi}$. A palladium foil of $0.5 \mathrm{~mm}$ thickness was used as a critical absorber for tin X-rays. Velocity calibration was performed against a $12 \mu \mathrm{m}$-thick $\alpha$-Fe foil at $R T .{ }^{57} \mathrm{Fe}$ isomer shifts $(\delta)$ are referred to $\alpha$ Fe at $R T$. Mössbauer spectra were fitted with a least-squares method program assuming Lorentzian peaks.

The electrical resistivity $(\rho)$ and Seebeck coefficient $(S)$ were measured simultaneously from ingots, from $300 \mathrm{~K}$ up to $675 \mathrm{~K}$ using ULVAC-ZEM3 device under partial helium pressure. A NETZSCH LFA-457 apparatus was used for measuring the thermal diffusivity under argon flow. The thermal conductivity $(\kappa)$ was determined as the product of the geometrical density, the thermal diffusivity and the theoretical heat capacity using Dulong-Petit approximation. The Wiedemann-Franz law, using a Lorentz number of $2.45 \times 10^{-8} \mathrm{~W} \Omega \mathrm{K}^{-2}$, was used to calculate the lattice thermal conductivity by 
subtracting the electronic contribution to the total thermal conductivity $\left(\kappa_{L}=\kappa-\kappa_{e}\right)$. The estimated measurements uncertainties are $6 \%$ for the Seebeck coefficient, $8 \%$ for the electrical resistivity, $11 \%$ for the thermal conductivity and $16 \%$ for the final figure of merit, $Z T$; they are in agreement with the reported uncertainties determined from round robin measurements on skutterudites. ${ }^{17}$

\section{Results and discussion}

\subsection{Crystal structure}

High-energy ball-milling of elemental powder mixture with different stoichiometries produces fine black powders. Typical PXRD pattern of these samples is presented in Fig. S1. The main diffraction peaks correspond to those of the sphalerite structure, i.e. a substructure of the natural germanite $\mathrm{Cu}_{26} \mathrm{Fe}_{4} \mathrm{Ge}_{4} \mathrm{~S}_{32} .{ }^{18}$ The latter is derived from the sphalerite by an ordered distribution of 32 cations $(24 \mathrm{Cu}, 4 \mathrm{Fe}, 4 \mathrm{Ge})$ on the $\mathrm{Zn}$ sites of the sphalerite with 2 additional copper cations located in empty tetrahedral sites (called 2a) of the sphalerite structure. At this stage, taking into account the large width of the diffraction peaks, it is not possible to conclude on the presence of germanite crystal in the as-ball-milled powder. Then, SPS was performed at $873 \mathrm{~K}$ to obtain dense, highly pure and well-crystallized samples. This synthesis process, i.e. combining mechanicalalloying and SPS, was previously proved to be efficient to prepare large quantity of high purity samples of other ternary and quaternary sulfides. ${ }^{7,11,19-21}$

All attempts to synthesize the sulfide $\mathrm{Cu}_{26} \mathrm{Fe}_{4} \mathrm{Ge}_{4} \mathrm{~S}_{32}$, corresponding to the natural mineral were unsuccessful, as shown from the PXRD pattern corresponding to this composition (Fig. S2). Mixtures, containing besides the main expected germanite type 
phase, the sulfide $\mathrm{Cu}_{4-\mathrm{x}} \mathrm{Fe}_{\mathrm{x}} \mathrm{S}_{4}(x \sim 0.4)$ and at least one other unidentified secondary phase, were obtained. At this point, the consideration of the charge balance in the natural mineral $\mathrm{Cu}_{16}^{+} \mathrm{Cu}^{2+}{ }_{10} \mathrm{Fe}^{3+}{ }_{4} \mathrm{Ge}^{4+}{ }_{4} \mathrm{~S}^{2-}{ }_{32}$ suggests that the germanite structure should be difficult to stabilize due to the large amount of $\mathrm{Cu}^{2+}$ besides $\mathrm{Cu}^{+}$species in the same tetrahedral sites. Indeed $\mathrm{Cu}^{2+}$, due to its Jahn-Teller effect, should favor the formation of distorted octahedral or pyramidal or square planar coordination with respect to the almost regular tetrahedral coordination that is imposed by the structure of the $\mathrm{Cu}^{2+}$-rich natural mineral $\mathrm{Cu}_{16}^{+} \mathrm{Cu}^{2+}{ }_{10} \mathrm{Fe}^{3+}{ }_{4} \mathrm{Ge}^{4+}{ }_{4} \mathrm{~S}^{2-}$. This suggests that this compound can only be obtained under high pressure as a mineral. To avoid high-pressure synthesis generally involved in the formation of natural minerals, we have investigated the possibility to increase the $\mathrm{Cu}^{+}$content by changing the charge balance between copper and iron. Keeping constant the global cationic stoichiometry with respect to that of the mineral, we increased the $\mathrm{Fe} / \mathrm{Cu}$ ratio according to the formula $\mathrm{Cu}_{26-x} \mathrm{Fe}_{4+x} \mathrm{Ge}_{4} \mathrm{~S}_{32}$. While $\mathrm{Cu}_{4-x} \mathrm{Fe}_{x} \mathrm{~S}_{4}$ impurities are still observed for $x=2$ and $x=3$, we were able to obtain a single-phase synthetic germanite sample for $x=4$, whose composition, $\mathrm{Cu}_{22} \mathrm{Fe}_{8} \mathrm{Ge}_{4} \mathrm{~S}_{32}$, is significantly different from that of the natural mineral $\mathrm{Cu}_{26} \mathrm{Fe}_{4} \mathrm{G}_{4} \mathrm{~S}_{32}$.

The room temperature ${ }^{57} \mathrm{Fe}$ Mössbauer spectrum of this compound fitted with two quadrupolar doublets (Fig. 1) and the corresponding hyperfine parameters (Table 1) clearly show that iron is present in the trivalent state only. This implies that the formula $\mathrm{Cu}_{20}^{+} \mathrm{Cu}^{2+}{ }_{2} \mathrm{Fe}^{3+}{ }_{8} \mathrm{Ge}^{4+}{ }_{4} \mathrm{~S}^{2-}{ }_{32}$ is characterized by a much higher $\mathrm{Cu}^{+} / \mathrm{Cu}^{2+}$ ratio than in the natural mineral $\mathrm{Cu}^{+}{ }_{16} \mathrm{Cu}^{2+}{ }_{10} \mathrm{Fe}^{3+}{ }_{4} \mathrm{Ge}^{4+}{ }_{4} \mathrm{~S}^{2-}$. Importantly, these results show that $\mathrm{Fe}^{3+}$ is distributed over two different crystallographic sites with practically equal abundances. Moreover, the room temperature isomer shifts of both $\mathrm{Fe}^{3+}$ sites of this synthetic germanite are similar to those of the two $\mathrm{Fe}^{3+}$ sites of stannoidite $\mathrm{Cu}_{8} \mathrm{Fe}_{3} \mathrm{Sn}_{2} \mathrm{~S}_{12}$, namely 
$0.29(3)$ and $0.40(3) \mathrm{mm} \cdot \mathrm{s}^{-1}{ }^{12}$, due to the close relationships between the two structures, which both consist of $\mathrm{CuS}_{4}$ and $\mathrm{FeS}_{4}$ tetrahedra.

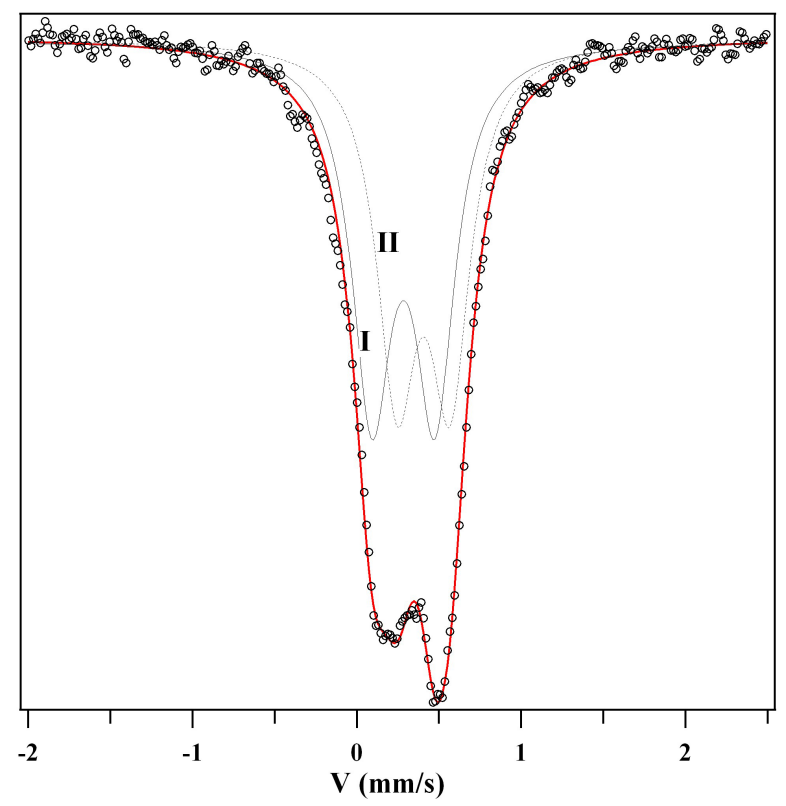

Figure 1. Room temperature ${ }^{57} \mathrm{Fe}$ Mössbauer spectrum of $\mathrm{Cu}_{22} \mathrm{Fe}_{8} \mathrm{Ge}_{4} \mathrm{~S}_{32}$.

\begin{tabular}{|c|c|c|c|c|}
\hline & $\begin{array}{c}\text { IS } \\
\mathrm{mm} \cdot \mathrm{s}^{-1} \\
( \pm 0.01)\end{array}$ & $\begin{array}{c}\mathrm{QS} \\
\mathrm{mm} \cdot \mathrm{s}^{-1} \\
( \pm 0.01)\end{array}$ & $\begin{array}{c}\mathrm{A} \\
\% \\
( \pm 3)\end{array}$ & $\begin{array}{c}\Gamma \\
\mathrm{mm} \cdot \mathrm{s}^{-1} \\
( \pm 0.01)\end{array}$ \\
\hline $\mathrm{Fe}^{3+} \mathrm{I}$ & 0.28 & 0.38 & 52 & 0.31 \\
\hline $\mathrm{Fe}^{3+}{ }_{\text {II }}$ & 0.41 & 0.32 & 48 & 0.31 \\
\hline
\end{tabular}

Table 1: ${ }^{57} \mathrm{Fe}$ hyperfine parameters: isomer shifts (IS), quadrupole splittings (QS), relative areas (A) and FWHM (I) for the two sites of the Mössbauer spectrum at $300 \mathrm{~K}$.

The PXRD pattern of this phase (Fig. 2) attests of its high purity: it can be indexed in a cubic cell $(a=10.589(1) \AA)$. The Rietveld refinements of the structure were carried out in the space group $P-43 n$, starting from the atomic positions previously established for the mineral germanite $\mathrm{Cu}_{26} \mathrm{Fe}_{4} \mathrm{Ge}_{4} \mathrm{~S}_{32} .{ }^{13}$ For these refinements, the occupancy factors of 
the cationic sites were kept unchanged with respect to the mineral, since iron, copper and germanium cannot be distinguished one from another from PXRD data due to their very close atomic numbers.

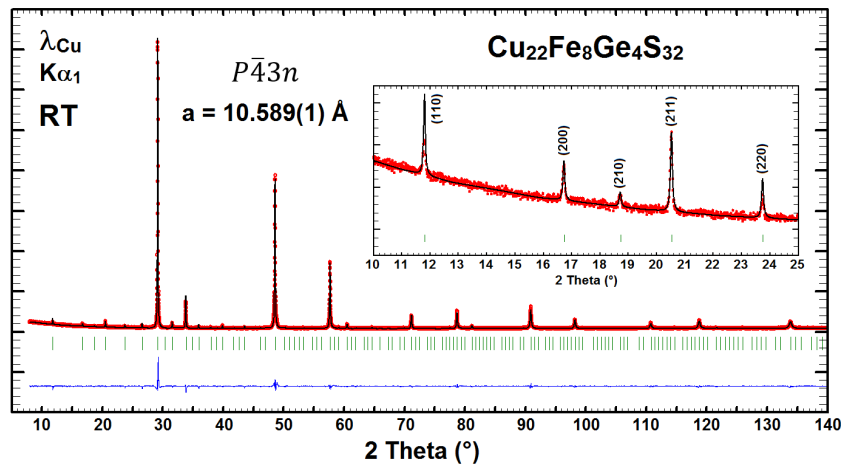

Figure 2. Rietveld refinement of the $P X R D$ pattern of $\mathrm{Cu}_{22} \mathrm{Fe}_{8} \mathrm{Ge}_{4} \mathrm{~S}_{32}$ recorded at $300 \mathrm{~K}$.

The refined atomic coordinates listed in Table 2 show that the structure of synthetic $\mathrm{Cu}_{22} \mathrm{Fe}_{8} \mathrm{Ge}_{4} \mathrm{~S}_{32}$ is directly derived from that of the natural mineral germanite ${ }^{13}$ $\mathrm{Cu}_{26}\left[\mathrm{Fe}_{4} \mathrm{Ge}_{4}\right] \mathrm{S}_{32}$ (Fig. 3a), i.e. it consists of a similar arrangement of edge and cornersharing $\mathrm{CuS}_{4}, \mathrm{FeS}_{4}$ and $\mathrm{GeS}_{4}$ tetrahedra. Thus, the distribution of the cationic species in the five independent fully occupied crystallographic sites of the structure, namely (2a, $6 \mathrm{c}, 6 \mathrm{~d}, 8 \mathrm{e}$, and $12 \mathrm{f}$ ), is not directly available from these refinements. However, bearing in mind that the $\mathrm{Ge}^{4+}$ and $\mathrm{Fe}^{3+}$ cations exhibit significantly smaller ionic radii, ${ }^{22}$ i.e. 0.39 and $0.49 \AA$ respectively, compared to $\mathrm{Cu}^{+}$and $\mathrm{Cu}^{2+}(0.60$ and $0.57 \AA$ respectively), two cationic distributions can be proposed by considering the interatomic distances (Table 3) together with Mössbauer results. Indeed, $\mathrm{Fe}^{3+}$ must be distributed equally in the unit cell (u.c.) between the smaller 6d (4 Fe/u.c.) and 8e (4 Fe/u.c.) sites. Due to its smaller size, $\mathrm{Ge}^{4+}$ will also tend to sit on the same sites as $\mathrm{Fe}^{3+}$. Thus the structure of the synthetic germanite (Fig. 3b) exhibits two possible cationic distributions over the $6 \mathrm{~d}$ and 8e sites: 
(I) " $\mathrm{Fe}_{4} \mathrm{Cu}_{2}$ " in 6d site (M2) and "Fe $4 \mathrm{Ge}_{4}$ " in 8e site (M5).

(II) " $\mathrm{Fe}_{4} \mathrm{Ge}_{2}$ " in $6 \mathrm{~d}$ site (M2) and " $\mathrm{Fe}_{4} \mathrm{Ge}_{2} \mathrm{Cu}_{2}$ " in 8e site (M5).

Model (I) is in agreement with the structure previously proposed by Tettenhorst et al. ${ }^{13}$ for the natural mineral germanite (Fig. 3a), where iron and germanium are distributed at random in the same " $\mathrm{Fe}_{4} \mathrm{Ge}_{4}$ " tetrahedral (8e) site. However, this model implies an average ionic radius for the $8 \mathrm{e}$ cations (" $\mathrm{Fe}_{4} \mathrm{Ge}_{4}$ ": $\mathrm{r}_{8 \mathrm{e}}=0.44 \AA$ ) smaller than that of the 6d cations (" $\mathrm{Fe}_{4} \mathrm{Cu}_{2}$ ": $\mathrm{r}_{6 \mathrm{~d}}=0.46 \AA$ ), which is in contradiction with the observed interatomic distances (Table 3) for these two sites. In contrast, for the model (II) which corresponds to an equal distribution of both iron and germanium between the two $8 \mathrm{e}$ and $6 \mathrm{~d}$ sites, the average ionic radii of the $8 \mathrm{e}$ cations (" $\mathrm{Fe}_{4} \mathrm{Ge}_{2} \mathrm{Cu}_{2}$ ": $\mathrm{r}_{8 \mathrm{e}}=0.493 \AA$ ) and of the $6 \mathrm{~d}$ cations ("Fe $\mathrm{Fe}_{2}$ ": $\mathrm{r}_{6 \mathrm{~d}}=0.457 \AA$ ) fit correctly with the interatomic distances (Table 2). Thus, the most probable cationic distribution in this synthetic germanite can be represented by the formula $\mathrm{Cu}_{20}\left[\mathrm{Fe}_{4} \mathrm{Ge}_{2}\right]_{6 \mathrm{~d}}\left[\mathrm{Fe}_{4} \mathrm{Ge}_{2} \mathrm{Cu}_{2}\right]_{8 \mathrm{e}} \mathrm{S}_{32}$. Unfortunately, this model cannot be confirmed by neutron diffraction. Indeed, the too close values of the coherent scattering lengths of the three different metallic species (Fe $9.45 \mathrm{fm}, \mathrm{Cu} 7.72$ $\mathrm{fm}, \mathrm{Ge} 8.18 \mathrm{fm}$ ) do not allow to distinguish the two cationic distributions proposed in models (I) and (II) from each other. A neutron study of isotopic ${ }^{57} \mathrm{Fe}(2.3 \mathrm{fm})$ synthetic germanite $\mathrm{Cu}_{22} \mathrm{Fe}_{8} \mathrm{Ge}_{4} \mathrm{~S}_{32}$ would be necessary to better understand the detailed structure of this sulfide. 


\begin{tabular}{cccccc}
\hline Atom & Site & $\mathrm{x}$ & $\mathrm{y}$ & $\mathrm{z}$ & Occ. \\
\hline $\mathrm{Cu} 1$ & $2 \mathrm{a}$ & 0 & 0 & 0 & 1.00 \\
$\mathrm{M} 2 *$ & $6 \mathrm{~d}$ & $1 / 4$ & 0 & $1 / 2$ & 1.00 \\
$\mathrm{Cu} 3$ & $6 \mathrm{c}$ & $1 / 4$ & $1 / 2$ & 0 & 1.00 \\
$\mathrm{Cu} 4$ & $12 \mathrm{f}$ & $0.2575(2)$ & 0 & 0 & 1.00 \\
$\mathrm{M} 5 * *$ & $8 \mathrm{e}$ & $0.2502(10)$ & $\mathrm{x}$ & $\mathrm{x}$ & 1.00 \\
$\mathrm{~S} 1$ & $8 \mathrm{e}$ & $0.1278(3)$ & $\mathrm{x}$ & $\mathrm{x}$ & 1.00 \\
$\mathrm{~S} 2$ & $24 \mathrm{i}$ & $0.3804(3)$ & $0.3679(1)$ & $0.1205(2)$ & 1.00 \\
\hline \multicolumn{5}{c}{$\mathrm{R}_{\text {Bragg }}=4.98, \mathrm{R}_{\mathrm{f}}=5.59, \mathrm{R}_{\mathrm{wp}}=6.20, \mathrm{R}_{\text {exp }}=2.96, \mathrm{c}^{2}=4.38$} \\
\hline *
\end{tabular}

*M2 corresponds to " $\mathrm{Fe}_{4} \mathrm{Cu}_{2}$ " in model (I) and to " $\mathrm{Fe}_{4} \mathrm{Ge}_{2}$ " in

model (II). **M5 corresponds to " $\mathrm{Fe}_{4} \mathrm{Ge}_{4}$ " in model (I) and to " $\mathrm{Fe}_{4} \mathrm{Ge}_{2} \mathrm{Cu}_{2}$ " in model (II).

Table 2: Atomic coordinates of the $\mathrm{Cu}_{22} \mathrm{Fe}_{8} \mathrm{Ge}_{4} \mathrm{~S}_{32}$ sample refined from powder $\mathrm{X}$-ray

diffraction data recorded at room temperature.

\begin{tabular}{cc}
\hline \multicolumn{2}{c}{ Distances $(\AA)$} \\
\hline $\mathrm{Cu} 1-\mathrm{S} 1$ & $4 \times 2.344(3)$ \\
$\mathrm{M} 2-\mathrm{S} 2$ & $4 \times 2.188(3)$ \\
$\mathrm{Cu} 3-\mathrm{S} 2$ & $4 \times 2.343(3)$ \\
$\mathrm{Cu} 4-\mathrm{S} 1$ & $2 \times 2.355(3)$ \\
$\mathrm{Cu} 4-\mathrm{S} 2$ & $2 \times 2.286(3)$ \\
$\mathrm{M} 5-\mathrm{S} 1$ & $1 \times 2.244(11)$ \\
$\mathrm{M} 5-\mathrm{S} 2$ & $3 \times 2.310(11)$ \\
\hline
\end{tabular}

Table 3: Interatomic distances deduced from Rietveld refinement of the powder X-ray diffraction data recorded at room temperature.

(a) $\mathrm{Cu}_{26} \mathrm{Fe}_{4} \mathrm{Ge}_{4} \mathrm{~S}_{32}$

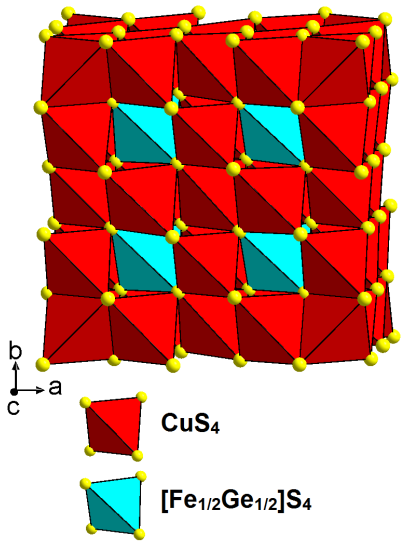

(b) $\quad \mathrm{Cu}_{22} \mathrm{Fe}_{8} \mathrm{Ge}_{4} \mathrm{~S}_{32}$

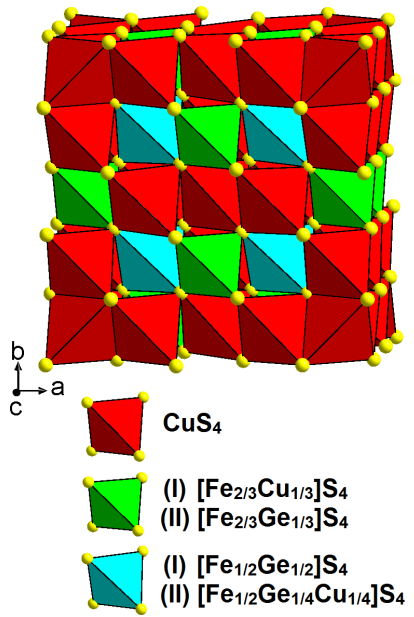

Figure 3. View of the crystal structure along the c axis of (a) natural germanite $\mathrm{Cu}_{26} \mathrm{Fe}_{4} \mathrm{Ge}_{4} \mathrm{~S}_{32}$ and (b) synthetic germanite $\mathrm{Cu}_{22} \mathrm{Fe}_{8} \mathrm{Ge}_{4} \mathrm{~S}_{32}$ (models I and II). 


\subsection{Thermoelectric properties}

Based on the above structural results, we have investigated the thermoelectric properties of three high purity samples, namely $\mathrm{Cu}_{22} \mathrm{Fe}_{8} \mathrm{Ge}_{4} \mathrm{~S}_{32}(x=4), \mathrm{Cu}_{22.2} \mathrm{Fe}_{7.8} \mathrm{Ge}_{4} \mathrm{~S}_{32}(x=3.8)$ and $\mathrm{Cu}_{22.4} \mathrm{Fe}_{7.6} \mathrm{Ge}_{4} \mathrm{~S}_{32}(x=3.6)$. Refinements of the PXRD patterns of the two latter compounds are presented in Supplementary Data (Fig. S3). Due to the presence of significant amounts of $\mathrm{Cu}_{4-x} \mathrm{Fe}_{x} \mathrm{~S}_{4}$ impurities, the electrical and thermal properties of the samples with compositions $\mathrm{Cu}_{26} \mathrm{Fe}_{4} \mathrm{Ge}_{4} \mathrm{~S}_{32}(x=0)$ and $\mathrm{Cu}_{24} \mathrm{Fe}_{6} \mathrm{Ge}_{4} \mathrm{~S}_{32}(x=2)$, are not presented here (See PXRD patterns in Fig. S2).

Figure 4 displays the electrical resistivity $\rho$ and Seebeck coefficient $S$ of the three $\mathrm{Cu}_{26-}$ ${ }_{x} \mathrm{Fe}_{4+x} \mathrm{Ge}_{4} \mathrm{~S}_{32}$ samples over the temperature range $300-575 \mathrm{~K}$. The electrical resistivity, which decreases slightly as the temperature increases, shows that these materials exhibit a semiconducting behavior, but are at the border of a metallic state. When the Fe content increases, the magnitude of the electrical resistivity increases at $300 \mathrm{~K}$ from 6.2 $\mathrm{m} \Omega \mathrm{cm}$ for $x=3.6$ to $9.3 \mathrm{~m} \Omega \mathrm{cm}$ for $x=4$. The evolution of the Seebeck coefficient versus temperature shows that all the compounds are $p$-type materials with $S$ values ranging from 113 to $128 \mu \mathrm{V} \mathrm{K}^{-1}$ at $300 \mathrm{~K}$. The Seebeck coefficient varies slightly with temperature and in opposite direction in respect to the electrical resistivity. This behavior can be explained by the fact that the conduction regime is intermediate between metallic and semiconducting. As expected, $S$ increases with $x$ in agreement with the electrical resistivity data. This trend suggests that $\mathrm{Fe}$ for $\mathrm{Cu}$ substitution provides additional electrons as observed in tetrahedrite and colusite samples for which the substitution of transition metals for $\mathrm{Cu}$ decreases the hole carrier concentration and concomitantly increases $\rho$ and $S^{4,5,7,23-27}$ Since Ge and Fe ions are strictly in the $\mathrm{Ge}^{4+}$ and $\mathrm{Fe}^{3+}$ states, the increase of $S$ and $\rho$ with $x$ is consistent with a decrease in $\mathrm{Cu}^{2+}$ content, i.e. of hole concentration. 
Considering the copper-rich natural mineral derivatives that have been investigated so far, it appears clearly that the transport properties of our synthetic $\mathrm{Cu}_{22} \mathrm{Fe}_{8} \mathrm{Ge}_{4} \mathrm{~S}_{32}$ germanite can be compared with those of the colusite family $\mathrm{Cu}_{26-x} T M_{x} \mathrm{~V}_{2} M_{6} \mathrm{~S}_{32}(T M=$ $\mathrm{Zn}, \mathrm{Co} ; M=\mathrm{Ge}, \mathrm{Sn}) .{ }^{6-8,25,27}$ Both compounds exhibit very close structural relationships: similar cubic unit cell $(a \sim 10.5 \AA)$ of space group $P-43 n$ and same anionic tetrahedral "S $\mathrm{S}_{32}$ " framework where 34 tetrahedral sites are fully occupied by the metallic cations. The difference between germanite and colusite structures lies in the cationic species occupancies in the 5 independent crystallographic sites (i.e. $2 \mathrm{a}, 6 \mathrm{c}, 6 \mathrm{~d}, 8 \mathrm{e}$, and $12 \mathrm{f}$ ). Indeed, in colusite, $\mathrm{Cu}$ atoms fully occupied the $6 \mathrm{~d}$, $8 \mathrm{e}$ and $12 \mathrm{f}$ sites, while $\mathrm{V}$ and $\mathrm{Sn}$ atoms fully occupied the $2 \mathrm{a}$ and $6 \mathrm{c}$ sites, respectively. Consequently, the crystal structure of germanite can be considered as a variant of colusite through different cation species distributions. Both tridimensional frameworks exhibit numerous percolation paths between edge- and corner-sharing $\mathrm{CuS}_{4}$ tetrahedra, allowing to generate rather high $p$-type conductivity, due to the presence of a large fraction of the sites occupied by univalent copper. However, the different distributions of metallic cations in the two structures and especially the introduction of additional $\mathrm{Fe}^{3+}$ cations on the copper sites in the synthetic germanite compared to the colusite probably hinders the mobility of carriers due to the creation of point defects. As a consequence, a higher resistivity is observed for the synthetic germanite whose electrical behavior is at the boundary between a semiconductor and a metal. Unfortunately, it was impossible to extract reliable carrier concentrations from the Hall effect data due to anomalous signal. Finally, such an assumption is also supported by the decrease of the mobility in the colusite series $\mathrm{Cu}_{26-x} \mathrm{Zn}_{x} \mathrm{~V}_{2} \mathrm{Sn}_{6} \mathrm{~S}_{32}{ }^{26}$ when $x$ increases. 


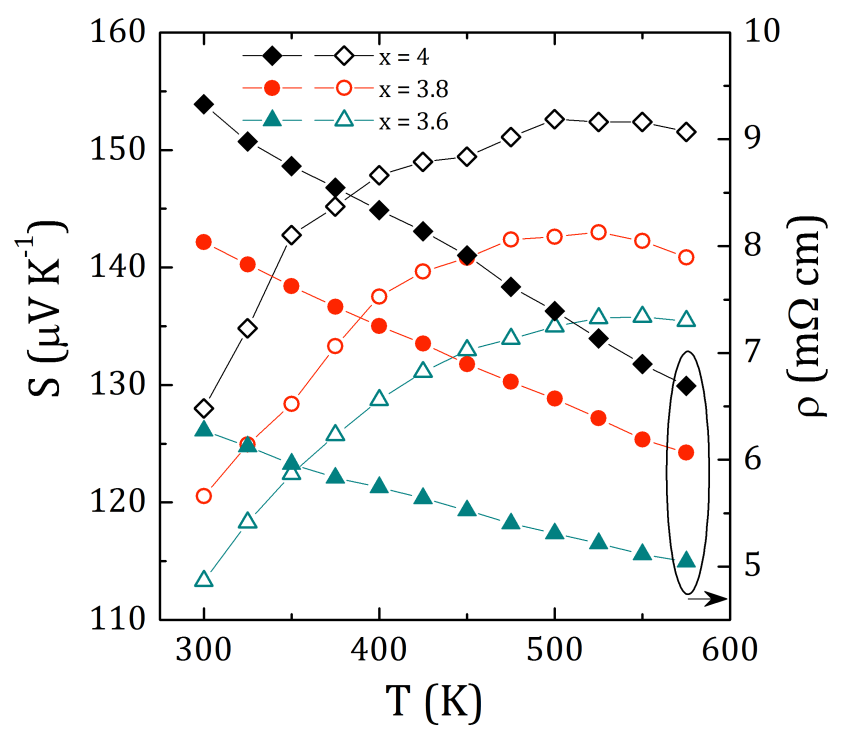

Figure 4. Temperature dependence of the Seebeck coefficient and the electrical resistivity in the $\mathrm{Cu}_{26-x} \mathrm{Fe}_{4+x} \mathrm{Ge}_{4} \mathrm{~S}_{32}$ series.

Temperature dependences of the power factor $(P F)$, presented in the inset of Figure 6 , show that the three samples have similar values on the full temperature range with a maximum around $3.5 \times 10^{-4} \mathrm{~W} \mathrm{~m}^{-1} \mathrm{~K}^{-2}$ at $575 \mathrm{~K}$. These values are comparable with the ones reported for $\mathrm{Cu}_{26-\mathrm{x}} \mathrm{Zn}_{\mathrm{x}} \mathrm{V}_{2} \mathrm{Sn}_{6} \mathrm{~S}_{32},{ }^{25,26}$ but remain significantly lower than those found in other colusite samples. ${ }^{6-8}$

The temperature dependences of the thermal conductivity are presented in Figure 5. All samples evidence the same temperature-dependence characterized by a decrease in the thermal conductivity from $300 \mathrm{~K}$ to $575 \mathrm{~K}$. The thermal conductivity values are similar, i.e. in the range of $\sim 1.7-1.8 \mathrm{~W} \mathrm{~m}^{-1} \mathrm{~K}^{-1}$ at $300 \mathrm{~K}$ and $\sim 1.2 \mathrm{~W} \mathrm{~m}^{-1} \mathrm{~K}^{-1}$ at $575 \mathrm{~K}$. Since the electronic contribution to the thermal conductivity is rather small due to relatively high electrical resistivity, the temperature dependences of the lattice thermal conductivity, displayed in the inset of Figure 5, are similar for the three compounds. This implies that the change in $x$ is not significant to affect phonon scattering. The magnitudes at $300 \mathrm{~K}$ are in agreement with the data published by Suekuni et al. ${ }^{25}$ and Bourgès et al. ${ }^{7}$ in some 
colusite compounds. These values are nevertheless much larger (twice) than those reported in other colusite samples. ${ }^{6,8}$ The origin of such intrinsically low thermal conductivity in certain colusite materials has been recently attributed to the presence of short-to-medium range structural defects, which correspond to disordered regions formed during the high temperature process (unpublished experiments). Finally, the temperature dependence of the dimensionless figure of merit, $Z T$, is given in Figure 6. All samples exhibit similar temperature dependence with a maximum $Z T$ value of 0.17 at $575 \mathrm{~K}$. This value is significantly less than the best values of $0.8-0.9$ of colusite compounds. Nevertheless, there is room for improvement in the ZT values of germanite compounds, by enhancing the carrier mobility in the $\mathrm{Cu}-\mathrm{S}$ conductive network and by creating short-to-medium range structural defects as observed recently in colusite compounds.

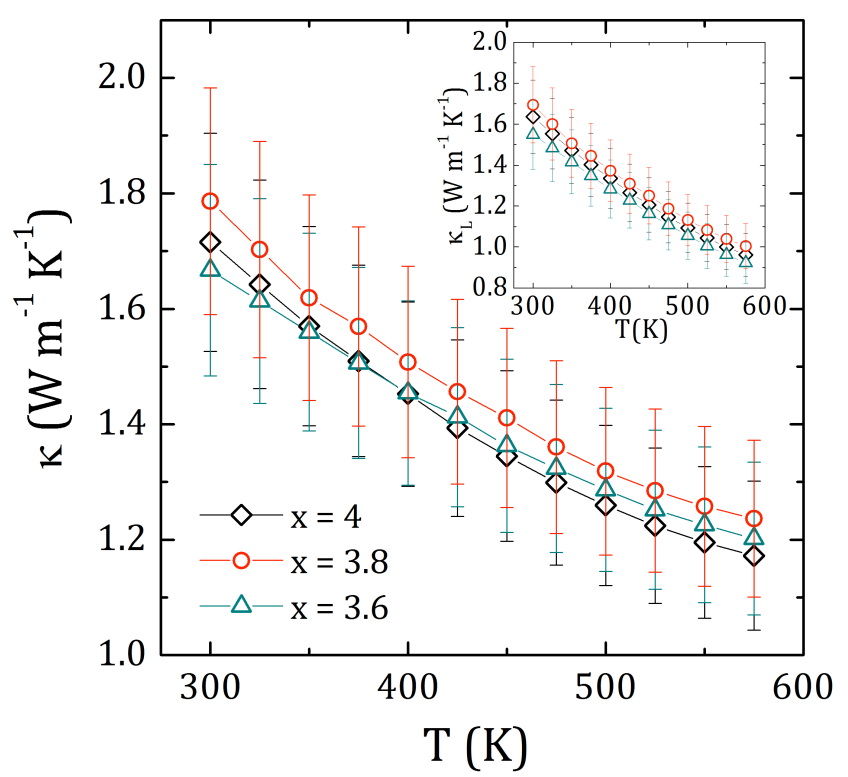

Figure 5. Temperature dependence of the thermal conductivity and its lattice contribution (Inset) in the $\mathrm{Cu}_{26-x} \mathrm{Fe}_{4+} \mathrm{Ge}_{4} \mathrm{~S}_{32}$ series. 


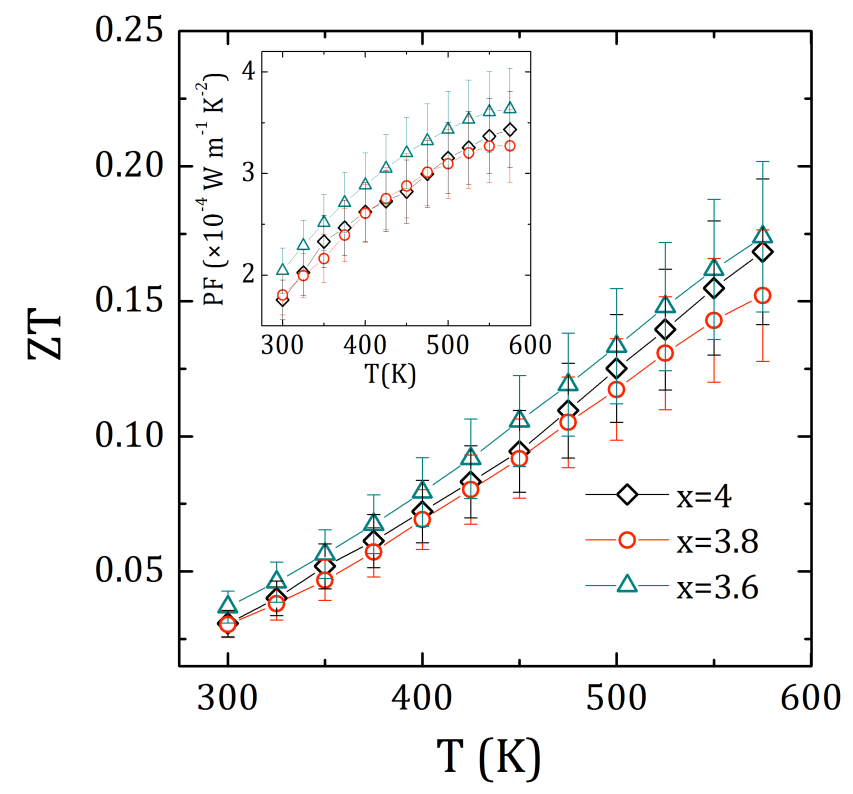

Figure 6. Temperature dependence of the figure of merit ZT and power factor (Inset) in the $\mathrm{Cu}_{26-x} \mathrm{Fe}_{4+x} \mathrm{Ge}_{4} \mathrm{~S}_{32}$ series.

\section{Conclusion}

This study shows the possibility to synthesize a $\mathrm{Cu}(\mathrm{I})$ rich sulfide $\mathrm{Cu}_{22} \mathrm{Fe}_{8} \mathrm{Ge}_{4} \mathrm{~S}_{32}$ with the germanite structure, which differs fundamentally from the natural mineral $\mathrm{Cu}_{26} \mathrm{Fe}_{4} \mathrm{Ge}_{4} \mathrm{~S}_{32}$ by its much higher $\mathrm{Cu}^{+} / \mathrm{Cu}^{2+}$ ratio. Thus, the coupled substitution of $\mathrm{Cu}^{+} / \mathrm{Fe}^{3+}$ for $\mathrm{Cu}^{2+}$ appears as a promising approach for increasing the $\mathrm{Cu}^{+}$content in sulfides with a tetrahedral framework. Bearing in mind that tetrahedral $\mathrm{Cu}-\mathrm{S}$ frameworks can exhibit high electronic conductivity, this point is of crucial importance for the generation of new $p$-type thermoelectrics. The evidence of thermoelectric 
properties for this synthetic germanite is in agreement with this viewpoint. Moreover, the ZT figure of merit of this sulfide, which is significantly smaller than that of the closely related colusite, strongly suggests that order-disorder cationic phenomena play a crucial role in carrier mobility leaving room for further improvement. These results demonstrate that the design of univalent copper sulfides by mimicking natural minerals and using charge balance compensation by various elements (not only iron) is a privileged route for the generation of new thermoelectrics.

\section{Associated Content}

The Supporting Information is available free of charge on the ACS Publications website at DOI:

Figure S1. Pattern matching of the PXRD patterns of as-ball-milled powder $\left(\mathrm{Cu}_{22} \mathrm{Fe}_{8} \mathrm{Ge}_{4} \mathrm{~S}_{32}\right)$ recorded at $300 \mathrm{~K}$.

Figure S2. Rietveld refinements of the PXRD patterns of $\mathrm{Cu}_{26} \mathrm{Fe}_{4} \mathrm{Ge}_{4} \mathrm{~S}_{32}$ (top) and $\mathrm{Cu}_{24} \mathrm{Fe}_{6} \mathrm{Ge}_{4} \mathrm{~S}_{32}$ (bottom) recorded at $300 \mathrm{~K}$.

Figure S3. Rietveld refinements of the PXRD patterns of $\mathrm{Cu}_{22.2} \mathrm{Fe}_{7.8} \mathrm{Ge}_{4} \mathrm{~S}_{32}$ (top) and $\mathrm{Cu}_{22.4} \mathrm{Fe}_{7.6} \mathrm{Ge}_{4} \mathrm{~S}_{32}$ (bottom) recorded at $300 \mathrm{~K}$.

\section{Acknowledgements}

The authors would like to thank Christelle Bilot, Jérôme Lecourt and Vincent Dorcet for technical support and the financial support of the French Agence Nationale de la Recherche (ANR), through the program Energy Challenge for Secure, Clean and Efficient Energy (Challenge 2, 2015, ANR-15-CE05-0027). 


\section{References}

(1) Liu, M. L.; Huang, F. Q.; Chen, L. D.; Chen, I. W. A Wide-Band-Gap P-Type Thermoelectric Material Based on Quaternary Chalcogenides of $\mathrm{Cu}_{2} \mathrm{ZnSnQ}_{4}$ (Q=S,Se). Appl. Phys. Lett. 2009, 94, 202103.

(2) Heinrich, C. P.; Day, T. W.; Zeier, W. G.; Snyder, G. J.; Tremel, W. Effect of Isovalent Substitution on the Thermoelectric Properties of the $\mathrm{Cu}_{2} \mathrm{ZnGeSe}_{4-\mathrm{x}} \mathrm{S}_{\mathrm{x}} . J$. Am. Chem. Soc. 2014, 136, 442-448.

(3) Suekuni, K.; Tsuruta, K.; Ariga, T.; Koyano, M. Thermoelectric Properties of Mineral Tetrahedrites $\mathrm{Cu}_{10} \mathrm{Tr}_{2} \mathrm{Sb}_{4} \mathrm{~S}_{13}$ with Low Thermal Conductivity. Appl. Phys. Express 2012, 5, 51201.

(4) Lu, X.; Morelli, D. T.; Xia, Y.; Zhou, F.; Ozolins, V.; Chi, H.; Zhou, X.; Uher, C. High Performance Thermoelectricity in Earth-Abundant Compounds Based on Natural Mineral Tetrahedrites. Adv. Energy Mater. 2013, 3, 342-348.

(5) Barbier, T.; Lemoine, P.; Gascoin, S.; Lebedev, O. I.; Kaltzoglou, A.; Vaqueiro, P.; Powell, A. V.; Smith, R. I.; Guilmeau, E. Structural Stability of the Synthetic Thermoelectric Ternary and Nickel-Substituted Tetrahedrite Phases. J. Alloys Compd. 2015, 634, 253-262.

(6) Suekuni, K.; Kim, F. S.; Nishiate, H.; Ohta, M.; Tanaka, H. I.; Takabatake, T. High-Performance Thermoelectric Minerals: Colusites $\mathrm{Cu}_{26} \mathrm{~V}_{2} \mathrm{M}_{6} \mathrm{~S}_{32}(\mathrm{M}=\mathrm{Ge}$, Sn). Appl. Phys. Lett. 2014, 105, 132107.

(7) Bourgès, C.; Gilmas, M.; Lemoine, P.; Mordvinova, N.; Lebedev, O. I.; Hug, E.; Nassif, V. M.; Malaman, B.; Daou, R.; Guilmeau, E. Structural Analysis and Thermoelectric Properties of Mechanically Alloyed Colusites. J. Mater. Chem. C 
2016, 4, 7455-7463.

(8) Kikuchi, Y.; Bouyrie, Y.; Ohta, M.; Suekuni, K.; Aihara, M.; Takabatake, T. Vanadium-Free Colusites $\mathrm{Cu}_{26} \mathrm{~A}_{2} \mathrm{Sn}_{6} \mathrm{~S}_{32}(\mathrm{~A}=\mathrm{Nb}$, Ta) for EnvironmentallyFriendly Thermoelectrics. J. Mater. Chem. A 2016, 4, 15207-15214.

(9) Qiu, P.; Zhang, T.; Qiu, Y.; Shi, X.; Chen, L. Sulfide Bornite Thermoelectric Material: A Natural Mineral with Ultralow Thermal Conductivity. Energy Environ. Sci. 2014, 7, 4000.

(10) Guélou, G.; Powell, A. V.; Vaqueiro, P. Ball Milling as an Effective Route for the Preparation of Doped Bornite: Synthesis, Stability and Thermoelectric Properties. J. Mater. Chem. C 2015, 3, 10624-10629.

(11) Kumar, V. P.; Barbier, T.; Lemoine, P.; Raveau, B.; Nassif, V.; Guilmeau, E. The Crucial Role of Selenium for Sulphur Substitution in the Structural Transitions and Thermoelectric Properties of $\mathrm{Cu}_{5} \mathrm{FeS}_{4}$ Bornite. Dalt. Trans. 2017, 46, 2174.

(12) Pavan Kumar, V.; Barbier, T.; Raveau, B.; Daou, R.; Malaman, B.; Le Caër, G.; Lemoine, P.; Guilmeau, E. Copper Hyper-Stoichiometry, the Key for the Optimization of Thermoelectric Properties in Stannoidite $\mathrm{Cu}_{8+\mathrm{x}} \mathrm{Fe}_{3-\mathrm{x}} \mathrm{Sn}_{2} \mathrm{~S}_{12} . J$. Phys. Chem. C 2017.

(13) Tettenhorst, R. T.; Corbato, C. E. Crystal Structure of Germanite, $\mathrm{Cu}_{26} \mathrm{Ge}_{4} \mathrm{Fe}_{4} \mathrm{~S}_{32}$, Determined by Powder X-Ray Diffraction. Am. Mineral. 1984, 69, 943-947.

(14) Rodríguez-Carvajal, J. Recent Advances in Magnetic Structure Determination by Neutron Powder Diffraction. Phys. B Condens. Matter 1993, 192 (1-2), 55-69.

(15) Roisnel, T.; Rodríguez-Carvajal, J. WinPLOTR: A Windows Tool for Powder 
Diffraction Patterns Analysis T. Mater. Sci. Forum 2001, 378-381, 118-123.

(16) Thompson, P.; Cox, D. E.; Hastings, J. B. Rietveld Refinement of DebyeScherrer Synchrotron X-Ray Data from A1203. J. Appl. Crystallogr. 1987, 20 (2), 79-83.

(17) Alleno, E.; Bérardan, D.; Byl, C.; Candolfi, C.; Daou, R.; Decourt, R.; Guilmeau, E.; Hébert, S.; Hejtmanek, J.; Lenoir, B.; Masschelein, P.; Ohorodnichuk, V.; Pollet, M.; Populoh, S.; Ravot, D.; Rouleau, O.; Soulier, M. Invited Article : A Round Robin Test of the Uncertainty on the Measurement of the Thermoelectric Dimensionless Figure of Merit of $\mathrm{Co}_{0.97} \mathrm{Ni}_{0.03} \mathrm{Sb}_{3}$. Rev. Sci. Instrum. 2015, 86, 11301.

(18) Wintenberger, M. Etude de La Structure Cristallographique et Magnétique de $\mathrm{Cu}_{2} \mathrm{FeGeS}_{4}$ et Remarque Sur La Structure Magnétique de $\mathrm{Cu}_{2} \mathrm{MnSnS}_{2}$. Mat. Res. Bull 1979, 14, 1195-1202.

(19) Barbier, T.; Rollin-Martinet, S.; Lemoine, P.; Gascoin, F.; Kaltzoglou, A.; Vaqueiro, P.; Powell, A. V.; Guilmeau, E. Thermoelectric Materials: A New Rapid Synthesis Process for Nontoxic and High-Performance Tetrahedrite Compounds. J. Am. Ceram. Soc. 2016, 99, 51-56.

(20) Barbier, T.; Lemoine, P.; Martinet, S.; Eriksson, M.; Gilmas, M.; Hug, E.; Guelou, G.; Vaqueiro, P.; Powell, A. V; Guilmeau, E. Up-Scaled Synthesis Process of Sulphur-Based Thermoelectric Materials. RSC Adv. 2016, 6, 1004410053.

(21) Bourgès, C.; Lemoine, P.; Lebedev, O. I.; Daou, R.; Hardy, V.; Malaman, B.; Guilmeau, E. Low Thermal Conductivity in Ternary $\mathrm{Cu}_{4} \mathrm{Sn}_{7} \mathrm{~S}_{16}$ Compound. Acta 
Mater. 2015, 97, 180-190.

(22) Shannon, R. D. Revised Effective Ionic Radii and Systematic Studies of Interatomic Distances in Halides and Chalcogenides. Acta Crystallogr. Sect. A 1976, 32, 751-767.

(23) Suekuni, K.; Tsuruta, K.; Kunii, M.; Nishiate, H.; Nishibori, E.; Maki, S.; Ohta, M.; Yamamoto, A.; Koyano, M. High-Performance Thermoelectric Mineral $\mathrm{Cu}_{12-}$ ${ }_{\mathrm{x}} \mathrm{Ni}_{\mathrm{x}} \mathrm{Sb}_{4} \mathrm{~S}_{13}$ Tetrahedrite. J. Appl. Phys. 2013, 113, 43712.

(24) Chetty, R.; Bali, A.; Naik, M. H.; Rogl, G.; Rogl, P.; Jain, M.; Suwas, S.; Mallik, R. C. Thermoelectric Properties of Co Substituted Synthetic Tetrahedrite. Acta Mater. 2015, 100, 266-274.

(25) Suekuni, K.; Kim, F. S.; Takabatake, T. Tunable Electronic Properties and Low Thermal Conductivity in Synthetic Colusites $\mathrm{Cu}_{26-\mathrm{x}} \mathrm{Zn}_{\mathrm{x}} \mathrm{V}_{2} \mathrm{M}_{6} \mathrm{~S}_{32}(\mathrm{x} \leq 4, \mathrm{M}=\mathrm{Ge}$, Sn). J. Appl. Phys. 2014, 116, 63706.

(26) Kim, F. S.; Suekuni, K.; Nishiate, H.; Ohta, M.; Tanaka, H. I.; Takabatake, T. Tuning the Charge Carrier Density in the Thermoelectric Colusite. J. Appl. Phys. 2016, 119, 175105.

(27) Bouyrie, Y.; Ohorodniichuk, V.; Sassi, S.; Masschelein, P.; Dauscher, A.; Candolfi, C.; Lenoir, B. High-Temperature Transport Properties of Colusite $\mathrm{Cu}_{24} \mathrm{~T}_{2} \mathrm{~V}_{2} \mathrm{Ge}_{6} \mathrm{~S}_{32}(\mathrm{~T}=\mathrm{Ni}, \mathrm{Co})$. J. Electron. Mater. 2017, 46, 2684-2690. 


\section{For Table of Content}

By mimicking copper rich sulfide minerals, a new germanite-type sulfide $\mathrm{Cu}_{22} \mathrm{Fe}_{8} \mathrm{Ge}_{4} \mathrm{~S}_{32}$ is designed as a promising thermoelectric material.

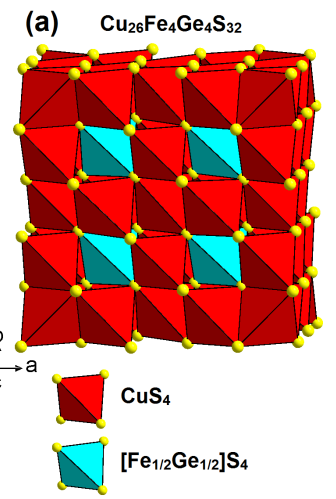

(b) $\mathrm{Cu}_{22} \mathrm{Fe}_{8} \mathrm{Ge}_{4} \mathrm{~S}_{32}$

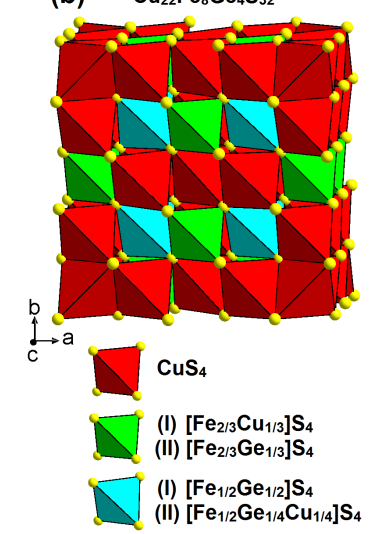

